Reproductive biology of the Ilex species (Aquifoliaceae) in Hong Kong, China

Anita C W Tsang; Richard T Corlett

Canadian Journal of Botany; Dec 2005; 83, 12; Academic Research Library

pg. 1645

\title{
Reproductive biology of the llex species (Aquifoliaceae) in Hong Kong, China
}

\author{
Anita C.W. Tsang and Richard T. Corlett
}

\begin{abstract}
Fourteen wild species of shrubs and trees in the dioecious genus $/ 1 e x$ occur in Hong Kong (22 N. 114 E). All species flowered and formed fruits once each year. Sex ratios at flowering were male biased in all but one large population studied and. in most cases. this bias could not be explained by earlier flowering in males or higher female mortality. Apis cerana accounted for $>87 \%$ of flower visits in all species and there was a significant positive relationship across species between the number of visits per flower per hour and the estimated mean number of flowers on a plant. The large green fruits of Ilex chapaensis Merr. were consumed only by masked palm civets, Paguma larrata, while the red or black fruits of other species were consumed by birds. The rate of fruit removal across species was positively related to sugar content and negatively related to phenolic and saponin contents. The mean number of pyrenes per fruit was $4.0-6.2$ and the mean percentage of pyrenes containing seeds was $49 \%-90 \%$. Most embryos were immature (heart shaped) at fruit maturity. but $<50 \%$ of embryos developed further in some species. Floral investment was 0.93-5.84 times higher in male plants, but total reproductive investment was $0.62-8.3$ higher in females.
\end{abstract}

Key words: germination, pollination. reproductive investment. seed dispersal. sex ratio.

Résumé : On retrouve 14 espèces d’arbustes et darbres sauvages du genre diö̈que $/ l e x$ à Hong Kong (22 N, $114 \mathrm{E}$ ). Toutes ces espèces fleurissent et fructifient une fois par année. À l'anthèse. les ratios sexuels ont un biais mâle chez toutes sauf une grande population étudiée et. dans la majorité des cas. ce biais ne peut pas être expliqué par une floraison plus hâtive chez les mâles ou une mortalité plus importante chez les femelles. L'Apis cerana réalise $>87 \%$ des visites chez l'ensemble des espèces. et on observe une corrélation positive significative. chez l'ensemble des espèces, entre le nombre de visites par fleur et par heure et le nombre moyen estimé de fleurs sur un plant. Les gros fruits verts de I'llex chapaensis Merr. sont consommés uniquement par la civette palmiste masquée. Paguma larrata, alors que les fruits rouges ou noirs des autres espèces sont consommés par les oiseaux. Le taux de prélèvement des fruits, che\% l'ensemble des espèces, est positivement relié à la teneur en sucre et négativement relié aux teneurs en phénols et en saponine. Le nombre moyen de pyrènes par fruit est de 4.0-6.2. et le pourcentage moyen des pyrènes contenant des graines est de $49 \%-90 \%$. La plupart des embryons sont immatures (cordiformes) à la maturité des fruits, mais $<50 \%$ se sont développés plus complètement chez certaines espèces. L'investissement floral est $0.93-5.84$ plus élevé chez les plantes mâles, mais l'investissement reproductif total est $0.62-8.3$ plus élevé chez les femelles.

Mots clés : germination, pollinisation, investissement reproductif. dispersion des graines. ratio sexuel.

[Traduit par la Rédaction]

\section{Introduction}

Ilex (holly) is the largest genus of woody dioecious plants, with at least 600 species (Galle 1997; Loizeau and Spichiger 2004). Although the genus is almost cosmopolitan. most species occur in mesic subtropical or tropical midmontane habitats in East Asia and America: there is only a single widespread species in sub-Saharan Africa, a single species in northern Australia, and a single species in most of Europe. Outside the tropics, Ilex species extend north to 64 and south to 33 , and the genus includes some of the most cold tolerant of all broad-leaved evergreens. Most species are shrubs or small trees, but in the tropics the genus

Received 15 February 2005. Published on the NRC Research Press Web site at http://canjbot.nrc.ca on 20 February 2006.

A.C.W. Tsang and R.T. Corlett. ${ }^{1}$ Department of Ecology \& Biodiversity. University of Hong Kong. Pokfulam Road. Hong Kong, China.

${ }^{1}$ Corresponding author (e-mail: corletı@hkucc.hku.hk). also includes some very large trees, a few epiphytic shrubs, and in Asia, apparently, a few climbers (Andrews 1998).

Despite the predominantly tropical-subtropical distribution of the genus, almost all the ecological studies of Ilex have been done on the relatively few temperate zone species. The combination of woodiness, dioecy, entomophily, and endozoochory is unique in most temperate floras, so the genus has received a disproportionate amount of scientific attention. The northern European species, I. aquifolium L., has become a model for woody dioecy (e.g., Obeso et al. 1998) and several North American and Japanese species have also been the subject of ecological studies. The Ilex species in the temperate zone are evergreen or deciduous dioecious shrubs or trees with small. insect-pollinated flowers that are often an important nectar source for bees (Krell 1988; Rathcke 1988). Female plants produce large, synchronous crops of small, low quality, chemically defended fruits that often persist for several months after ripening and are eaten mostly by birds, particularly thrushes (Snow and Snow 1988; Gorchov 1990; Gargiullo and Stiles 1991; Carr 1992: Obeso and Fernandez-Calvo 2003). The seeds are in- 
Table 1. The Ilex species in Hong Kong.

\begin{tabular}{|c|c|c|c|c|}
\hline Species & Subgenus $^{a}$ & Section $^{a}$ & $\begin{array}{l}\text { Maximum } \\
\text { height }(\mathrm{m})^{b}\end{array}$ & Status $^{b}$ \\
\hline Ilex asprella Benth. & Prinos & Prinoides & 5.2 & Very common \\
\hline Ilex chapaensis Merr. & Aquifolium & Aquifolium & 20.0 & Rare \\
\hline Ilex cinerea Benth. & Aquifolium & Aquifolium & 7.1 & Uncommon \\
\hline Ilex dasyphylla Merr. & Byronia & Lioprinus & 3.5 & Very rare \\
\hline Ilex ficoidea Hemsl. & Aquifolium & Aquifolium & 15.0 & Uncommon \\
\hline Ilex graciliflora Benth. & Aquifolium & Aquifolium & 8.6 & Uncommon \\
\hline Ilex hanceana Maxim. & Aquifolium & Pseudoaquifolium & 6.0 & Uncommon \\
\hline Ilex kwangtungensis Merr. & Byronia & Lioprinus & 15.4 & Rare \\
\hline Ilex limii C.J. Tseng & Byronia & Lioprinus & 5.0 & Rare \\
\hline Ilex lohfauensis Merr. & Byronia & Lioprinus & 3.5 & Uncommon \\
\hline Ilex memecylifolia Benth. & Aquifolium & Pseudoaquifolium & 4.8 & Common \\
\hline Ilex pubescens Hook. \& Arn. & Aquifolium & Pseudoaquifolium & 5.1 & Very common \\
\hline Ilex rotunda Thunb. & Byronia & Lioprinus & 5.6 & Uncommon \\
\hline Ilex viridis Benth. & Byronia & Lioprinus & 10.2 & Common \\
\hline
\end{tabular}

dividually enclosed by woody endocarp and have undeveloped embryos when the fruits reach maturity, resulting in dormancy and a seed bank that persists for only a few years (Hu 1975; Naka and Yoda 1984; Baskin and Baskin 2001; Shelton and Cain 2002; Arrieta and Suárez 2005).

One major objective of the study reported here was to compare the reproductive biology of the 14 native species of Ilex in Hong Kong, on the northern margins of the East Asian tropics, with that of the better-known temperate-zone species. The Hong Kong species (Table 1) range from shrubs to large trees and represent all three subgenera and 5 of the 12 sections recognized by Galle (1997), although the available phylogenetic information (which includes only two Hong Kong species) suggests that this morphological classification is not an accurate representation of the real relationships among the taxa (Cuénoud et al. 2000; Manen et al. 2002). The second objective was to make use of the coexistence in the same area of 14 congeneric species, which have morphologically similar flowers and fruits and which are exposed to the same fauna, to investigate the role of flower and fruit characters in attracting pollinators and seed dispersal agents. Two major hypotheses were tested: firstly, that pollinator visitation rates are related to the traits of individual flowers (flower size and nectar production) and of floral displays (number of flowers per branch and per plant) and, secondly, that fruit removal rates are related to pulp chemistry (positively to nutritional chemistry, negatively to defensive chemistry) and the percentage of fruit mass consisting of pulp.

\section{Materials and methods}

\section{Study area and species}

Hong Kong $\left(22^{\circ} \mathrm{N}, 114^{\circ} \mathrm{E}\right)$ consists of a biogeographically arbitrary $1100 \mathrm{~km}^{2}$ of the South China coast and nearby islands. It has a population of almost 7 million people, but the rugged topography means that only $20 \%$ of the land area is urbanized (Dudgeon and Corlett 2004). Most of Hong Kong is underlain by igneous rocks of Jurassic age. The climate is subtropical, with distinct hot, humid and dry, cool seasons.
Mean annual rainfall in the study sites is $1600-3000 \mathrm{~mm}$, with about $80 \%$ falling between May and September. Mean annual temperature ranges from $22.8{ }^{\circ} \mathrm{C}$ in lowland $\mathrm{Kow}-$ Ioon to $18.3{ }^{\circ} \mathrm{C}$ near the summit of the highest hill, Tai Mo Shan $(957 \mathrm{~m})$. Subzero temperatures occur annually at the highest altitudes and less frequently down to around 400$450 \mathrm{~m}$ on Tai Mo Shan and to sea-level in northern Hong Kong. Deforestation of coastal South China started at least 1000 years ago and the original forest cover of the Hong Kong region had largely disappeared by the nineteenth century, except for some tiny, disturbed patches in inaccessible sites at high altitude (Dudgeon and Corlett 2004). There are also a number of small ( $<4$ ha), old-forest patches of uncertain origin preserved for feng shui reasons behind traditional villages, but most non-urban areas are now covered in firemaintained grassland, shrubland, secondary forest, or exotic plantations (Zhuang and Corlett 1997).

The two main study sites, on Tai Mo Shan and on the western half of Hong Kong Island, were chosen because of accessibility and the diversity of Ilex species present. Ilex asprella, I. ficoidea, I. kwangtungensis, I. lohfauensis, I. pubescens, I. rotunda, and I. viridis occur on Tai Mo Shan, and this is one of only two sites in Hong Kong with I. lohfauensis. Western Hong Kong Island has I. asprella, I. chapaensis, I. cinerea, I. ficoidea, I. graciliflora, I. hanceana, I. memecylifolia, I. pubescens, and I. viridis. Additional sites were included as replicate populations and for two rare species, I. kwangtungensis and I. cf. limii, which did not occur in the main study area. A 14th species, I. dasyphylla, is known in Hong Kong only from a single male plant on Lantau Island. A possible 15 th species is known only from six individuals, on Ma On Shan, that were not seen to reproduce, so it was not considered further. Because of their differing relative abundances and accessibilities, the number of individual plants sampled varied considerably among species and most aspects of reproductive biology could not be evaluated for all species.

\section{Flower biology}

The reproductive phenology (flowering period and the pe- 
Table 2. Sex ratios at flowering of Ilex populations in Hong Kong.

\begin{tabular}{|c|c|c|c|c|c|c|c|}
\hline Species & Site & $n$ & $\begin{array}{l}\text { Male:female } \\
\text { ratio }\end{array}$ & Male & Female & $\begin{array}{l}\text { Nonflowering } \\
\text { plants }\end{array}$ & $\begin{array}{l}G \text { test } \\
p \text { value }\end{array}$ \\
\hline \multirow[t]{5}{*}{ I. asprella } & Pok & 121 & 2.11 & 74 & 35 & 12 & 0.0002 \\
\hline & TMS & 108 & 1.27 & 56 & 44 & 8 & 0.2296 \\
\hline & SS & 148 & 1.12 & 75 & 67 & 6 & 0.5019 \\
\hline & PSL & 131 & 1.26 & 68 & 54 & 9 & 0.2045 \\
\hline & $\mathrm{KL}$ & 81 & 2.68 & 51 & 19 & 11 & 0.0001 \\
\hline \multirow[t]{2}{*}{ 1. chapaensis } & $\mathrm{MN}$ & 14 & 1.17 & 7 & 6 & 1 & 0.7814 \\
\hline & WKT & 11 & 1.00 & 5 & 5 & 1 & 1.0000 \\
\hline \multirow[t]{2}{*}{ I. cinerea } & Pok & 77 & 0.87 & 33 & 38 & 6 & 0.5528 \\
\hline & PSL & 16 & 0.78 & 7 & 9 & 0 & 0.6166 \\
\hline \multirow[t]{2}{*}{ I. ficoidea } & Pok & 44 & 1.36 & 19 & 14 & 11 & 0.3832 \\
\hline & $\mathrm{MN}$ & 12 & 1.33 & 4 & 3 & 5 & 0.7050 \\
\hline I. graciliflora & TT & 72 & 2.00 & 46 & 23 & 3 & 0.0052 \\
\hline \multirow[t]{2}{*}{ I. hanceana } & Pok & 51 & 1.29 & 27 & 21 & 3 & 0.3859 \\
\hline & SS & 22 & 1.50 & 9 & 6 & 7 & 0.4370 \\
\hline I. kwangtungensis & $\mathrm{PU}$ & 14 & 1.00 & 3 & 3 & 8 & 1.0000 \\
\hline I. lohfauensis & TMS & 83 & 1.82 & 51 & 28 & 4 & 0.0091 \\
\hline \multirow[t]{2}{*}{ I. memecylifolia } & Pok & 18 & 0.80 & 4 & 5 & 9 & 0.7386 \\
\hline & Abe & 47 & 1.44 & 26 & 18 & 3 & 0.2265 \\
\hline I. pubescens & Pok & 117 & 1.86 & 65 & 35 & 17 & 0.0025 \\
\hline I. rotunda & TMS & 38 & 1.08 & 13 & 12 & 13 & 0.8415 \\
\hline I. viridis & Pok & 91 & 1.11 & 39 & 35 & 17 & 0.6419 \\
\hline
\end{tabular}

riod with ripe fruits) of all Ilex species was recorded at several sites from numerous visits in 2001-2004. At 1-5 sites for each species (Table 2), the entire accessible population of reproductive size (i.e., all plants at least as large as the smallest plant we have seen flowering) was sexed at flowering time to determine the sex ratio. Where possible, at least 20 individuals of each species and sex, growing in full sunlight or in the typical light environment for the species, were selected for more detailed studies, but the numbers were smaller for some less common species. In most cases, all individuals came from a single large population at a typical site for the species, but data were pooled from two populations for some less common species. Floral longevity was examined by labeling 10 haphazardly selected flower buds of each sex and species before they opened and then observing them daily until the corolla wilted or detached. The number of flowers or flower buds was counted on a standard 8-mm-diameter branch on each individual and. for female plants, the fruit set (as a percentage of total flowers) was also determined. The corolla diameters of fully opened flowers, flower colors, and flower dry masses were also recorded. The volume of nectar was measured by micropipette between 1230 and 1800 (the main period of nectar secretion in female plants of most species) on a sunny day, and the sugar concentration was determined with a hand-held refractometer (S/Mill-E, Atago Co. Ltd., Tokyo, Japan). If the volume of nectar secreted from a flower was less than $0.2 \mu \mathrm{L}, 15 \mu \mathrm{L}$ of distilled water was added to the flower before the nectar was sampled. A Dionex HPLC system with an ED40 electrochemical detector (Dionex Corp.. Sunnyvale, California) was used to determine the proportions of sucrose, glucose, and fructose in the nectar samples after storage at $-20 \mathrm{C}$. Pollen/ovule ratios were estimated for 1-2 flower buds from two haphazardly selected individuals of each sex of each species. Ovules were counted by dissection under a stereomicroscope. All anthers in each flower were submerged in $500 \mu \mathrm{L}$ of $10 \mathrm{~mol} / \mathrm{L}$ sodium hydroxide solution and completely macerated with a pair of extra fine forceps. An aliquot of $5 \mu \mathrm{L}$ was then transferred to a haemocytometer and the number of pollen grains was counted.

Flower visitors were observed casually throughout the flowering period and systematically on several calm and clear days for all except the three rarest species. Part of a flowering plant was observed for $20-60 \mathrm{~min}$ and the number of visitors, number of visits, and the number of open flowers were recorded. The total number of open flowers on the whole plant was also estimated. Only visitors that attempted to collect nectar or pollen were recorded. Visitors were collected and identified to species or genus level where possible. All Ilex species were also observed at night

\section{Fruit and seed biology}

In 2001-2003, for each species and site, depending on availability, 3-5 fruiting plants were haphazardly selected. and 20-100 ripe fruits were haphazardly collected from each individual plant. Fruits were determined to be ripe from their colour and attractiveness to frugivores. Within $2 \mathrm{~h}$ after fruit collection, 20-30 undamaged fruits were randomly selected for each individual plant. Fruit dimensions (height, length, and width), fresh and dry mass, and the number of pyrenes per fruit were recorded. For the pyrenes. dimensions (length and width), fresh and dry mass. and the percentage containing seeds were recorded. Fruits and pyrenes were oven-dried at $70 \mathrm{C}$ for a minimum of $7 \mathrm{~d}$ to obtain dry masses. Embryo maturity was determined from the shape of the embryo in 40 seeds of each species: embryos of Ilex undergo development from an undeveloped heartshaped stage. through a partly developed torpedo stage, to the mature stage (Sansberro et al. 1998). Germination tests 
Fig. 1. The flowering periods of female (F) and male (M) plants of the Ilex species in Hong Kong.

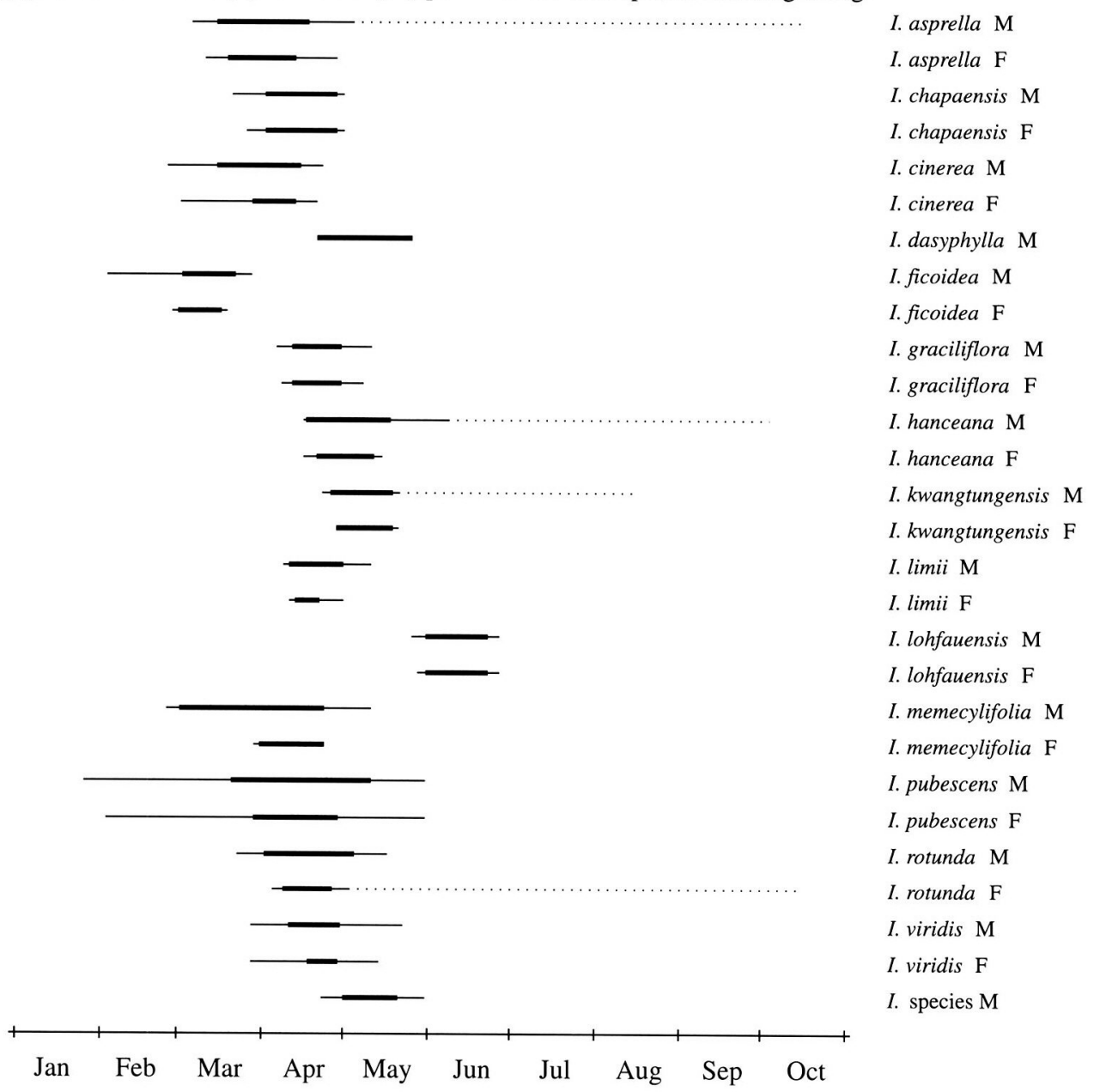

Fig. 2. The fruiting periods of the Ilex species in Hong Kong.

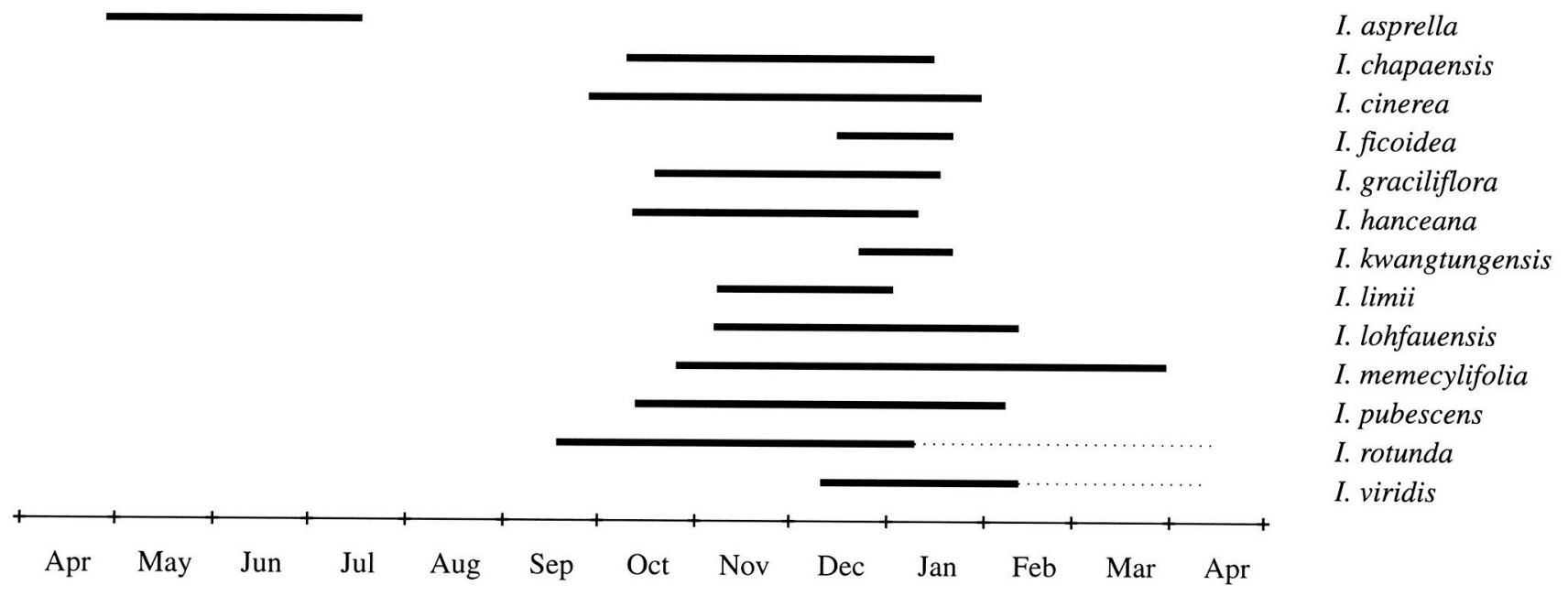

were carried out in the greenhouse by sowing 50-250 pyrenes of each species in soil.

For the analysis of fruit pulp chemistry, ripe fruits of 11 Ilex species were collected in 2002-2003 and stored at $-20{ }^{\circ} \mathrm{C}$. Before analysis, the fruits were freeze-dried, the pyrenes were removed, and the fruit pulp ground to pass through a 40-mesh screen. Extracts for sugar and phenolic analysis were made using $70 \%$ alcohol. Sugar content of fruit extracts was determined using the same method as was used for nectar sugars. Total phenolics were determined as described by Price and Butler (1977). Phenolics are reported as percent dry mass of tannic acid. Saponin content was determined as described by Hiai et al. (1976), with diosgenin as a standard. Tannin content was deter- 
Table 3. Flower characters and fruit set of Ilex species in Hong Kong.

\begin{tabular}{|c|c|c|c|c|c|c|c|c|}
\hline Species & Sex & $\begin{array}{l}\text { Petal } \\
\text { color }^{a}\end{array}$ & $\begin{array}{l}\text { Diameter } \\
(\mathrm{mm})\end{array}$ & $\begin{array}{l}\text { Nectar pro- } \\
\text { duction }^{b}\end{array}$ & $\begin{array}{l}\text { Sugars } \\
(\mathrm{G}: \mathrm{S}: \mathrm{F})^{c}\end{array}$ & $\begin{array}{l}\text { Apis visit } \\
\text { rate }^{d}\end{array}$ & $\begin{array}{l}\text { Total diurnal } \\
\text { visit rate }^{d}\end{array}$ & $\begin{array}{l}\text { Fruit set } \\
(\%)\end{array}$ \\
\hline \multirow[t]{2}{*}{ I. asprella } & M & w & 6.3 & 0.06 & 63:00:37 & 1.02 & 1.11 & \\
\hline & $\mathrm{F}$ & w & 6.2 & 0.07 & $63: 08: 29$ & 0.67 & 0.74 & 64 \\
\hline \multirow[t]{2}{*}{ I. chapaensis } & M & w & 13.0 & & & 2.49 & 2.64 & \\
\hline & $\mathrm{F}$ & w & 13.3 & & & 1.37 & 1.45 & 40 \\
\hline \multirow[t]{2}{*}{ I. cinerea } & M & $\mathrm{g}, \mathrm{y}$ & 7.8 & 0.81 & $45: 19: 36$ & 8.04 & 8.39 & \\
\hline & $\mathrm{F}$ & $\mathrm{g}, \mathrm{y}$ & 6.0 & 0.34 & $35: 27: 38$ & 5.97 & 6.15 & 72 \\
\hline I. dasyphylla & M & $\mathrm{p}$ & 6.7 & & & & & \\
\hline \multirow[t]{2}{*}{ I. ficoidea } & M & $w, y, g$ & 8.0 & 0.23 & & 4.04 & 4.18 & \\
\hline & $\mathrm{F}$ & $\mathrm{w}, \mathrm{y}, \mathrm{g}$ & 7.2 & 0.09 & & 1.65 & 1.73 & 37 \\
\hline \multirow[t]{2}{*}{ I. graciliflora } & M & $w, y$ & 5.4 & & & 4.14 & 4.23 & \\
\hline & $\mathrm{F}$ & w & 5.6 & & & 2.70 & 2.77 & 46 \\
\hline \multirow[t]{2}{*}{ I. hanceana } & M & w & 6.1 & 0.06 & $25: 53: 22$ & 2.38 & 2.44 & \\
\hline & $\mathrm{F}$ & w & 5.9 & 0.04 & $26: 33: 41$ & 0.75 & 0.79 & 22 \\
\hline \multirow[t]{2}{*}{ I. kwangtungensis } & M & $\mathrm{p}$ & 7.0 & & & & & \\
\hline & $\mathrm{F}$ & $\mathrm{p}$ & 9.9 & & & & & 37 \\
\hline \multirow[t]{2}{*}{ I. limii } & M & $\mathrm{p}$ & 5.4 & & & & & \\
\hline & $\mathrm{F}$ & $\mathrm{p}$ & 5.4 & & & & & 30 \\
\hline \multirow[t]{2}{*}{ I. lohfauensis } & M & $w, p$ & 4.4 & 0.05 & $45: 00: 55$ & 5.61 & 5.76 & \\
\hline & $\mathrm{F}$ & $\mathrm{w}, \mathrm{p}$ & 5.1 & 0.05 & $39: 34: 27$ & 2.53 & 2.67 & 8 \\
\hline \multirow[t]{2}{*}{ I. memecylifolia } & M & $\mathrm{w}$ & 6.7 & 0.18 & $60: 12: 28$ & 3.02 & 3.47 & \\
\hline & $\mathrm{F}$ & $\mathrm{w}$ & 8.4 & 0.22 & $64: 10: 26$ & 2.42 & 2.62 & 25 \\
\hline \multirow[t]{2}{*}{ I. pubescens } & M & $\mathrm{w}, \mathrm{p}$ & 5.8 & 0.07 & $45: 29: 26$ & 2.72 & 2.78 & \\
\hline & $\mathrm{F}$ & $\mathrm{w}, \mathrm{p}$ & 5.8 & 0.07 & $30: 31: 39$ & 1.20 & 1.24 & 57 \\
\hline \multirow[t]{2}{*}{ I. rotunda } & M & $w, y$ & 4.9 & 0.17 & $34: 21: 45$ & 12.18 & 12.46 & \\
\hline & $\mathrm{F}$ & $w, y$ & 4.4 & 0.07 & $33: 37: 30$ & 11.02 & 11.20 & 60 \\
\hline \multirow[t]{2}{*}{ I. viridis } & M & $\mathrm{w}, \mathrm{p}$ & 6.9 & 0.09 & & 2.49 & 2.53 & \\
\hline & $\mathrm{F}$ & $\mathrm{w}, \mathrm{p}$ & 8.1 & 0.07 & & 2.22 & 2.26 & 48 \\
\hline
\end{tabular}

\footnotetext{
${ }^{a} \mathrm{w}$, white; g, green; y:,yellow; p, pink.

${ }^{b}$ Measured as mg sugar flower $^{-1} \cdot h^{-1}$.

${ }^{c} \mathrm{G}$, glucose; $\mathrm{S}$, sucrose; $\mathrm{F}$, fructose.

${ }^{d}$ Measured as visits flower ${ }^{-1} \cdot \mathrm{h}^{-1}$.
}

mined using a radial diffusion method (Hagerman 1987), with tannic acid as a standard.

Observations of frugivory events were made with binoculars at weekly intervals during each fruiting period for all species except the three least abundant species and I. memecylifolia, which had very few ripe fruits at any one time. For $I$. asprella, $I$. chapaensis, $I$. cinerea, I. graciliflora, and I. rotunda, an individual tree with more than 200 fruits was observed. For I. lohfauensis, which has few fruits on a plant, observations were carried out where several fruiting individuals could be observed simultaneously. For I. hanceana, I. pubescens, and I. viridis, observations were made along a pre-set route at the two main study sites. For $I$. chapaensis, additional observations were made at night because daytime observations found no diurnal visitors, but there was evidence from fallen fruit remains that vertebrates were visiting all fruiting trees. In each observation period, the number of ripe fruits on the observed plant(s), the number and species of birds feeding on the fruits, and the time interval between arrival and departure for each bird were recorded.

\section{Data analysis}

The absence of a reliable phylogeny for most (12 of 14) Hong Kong Ilex species made it impossible to control for possible phylogenetic effects during statistical analyses. This may have resulted in inflation of the degrees of freedom, although the broad taxonomic spread of the species studied (all three subgenera and 5 of 12 currently recognized sections) should reduce the seriousness of this problem. A potentially even bigger problem arises from the large number of variables measured for each species in this study ( $>30$ for the common species) and the resulting temptation to simultaneously test many statistical hypotheses, thus increasing the number of falsely rejected null hypotheses. We have minimized this risk by making only a small number of planned statistical tests, based on hypotheses in the relevant literature and (or) expected functional relationships. All statistical tests were carried out using SigmaStat for Windows version 3.0.1.

\section{Results}

\section{Phenology}

All Ilex species in Hong Kong are evergreen, except I. asprella and $I$. chapaensis. All species flowered and fruited once a year, with little difference among years, except for the forest trees, I. chapaensis and I. kwangtungensis, in which the numbers of flowers produced, but not their timing, varied considerably among years. In 2002, for which the most de- 
Table 4. Relative reproductive investment by female (F) and male (M) plants of Ilex species in Hong Kong.

\begin{tabular}{lllll}
\hline Species & $\begin{array}{l}\text { Flower } \\
\text { no. (F:M) }\end{array}$ & $\begin{array}{l}\text { Flower dry } \\
\text { mass (F:M) }\end{array}$ & $\begin{array}{l}\text { Floral investment } \\
(\mathrm{F}: \mathrm{M})^{a}\end{array}$ & $\begin{array}{l}\text { Reproductive in- } \\
\text { vestment (F:M) }\end{array}$ \\
\hline I. asprella & 0.27 & 1.47 & 0.40 & 5.09 \\
I. chapaensis & 0.08 & 2.06 & 0.17 & 4.30 \\
I. cinerea & 0.18 & 1.45 & 0.27 & 4.79 \\
I. ficoidea & 0.16 & 2.43 & 0.38 & 3.33 \\
I. graciliflora & 0.15 & 2.00 & 0.31 & 2.66 \\
I. hanceana & 0.22 & 2.27 & 0.50 & 2.20 \\
I. kwangtungensis & 0.36 & 1.89 & 0.68 & 4.83 \\
I. limii & 0.25 & 2.13 & 0.53 & 8.33 \\
I. lohfauensis & 0.19 & 2.00 & 0.37 & 0.62 \\
I. memecylifolia & 0.42 & 2.56 & 1.08 & 3.72 \\
I. pubescens & 0.40 & 1.00 & 0.40 & 3.48 \\
I. rotunda & 0.30 & 1.00 & 0.30 & 3.08 \\
I. viridis & 0.41 & 1.97 & 0.81 & 8.29 \\
\hline
\end{tabular}

${ }^{a}$ Floral investment $=$ no. of flowers on 8 -mm-diameter branch $\times$ dry mass of the flower.

${ }^{b}$ Reproductive investment of male $=$ no. of flowers on 8 -mm-diameter branch $\times$ dry mass of flower; reproductive investment of female $=$ (no. of flowers on 8 -mm-diameter branch $\times$ dry mass of flower) + (no. of fruits on 8-mm-diameter branch $x$ dry mass of fruit).

tailed information is available, most species flowered between March and May, although some individuals of I. pubescens started flowering earlier, and all I. lohfauensis flowered in June (Fig. 1). Ilex asprella fruited in summer, while fruits of the other species became ripe between late September and mid-December (Fig. 2). Fruit ripening was more or less synchronous at the individual level in all species except $I$. memecylifolia, in which ripening was spread over several months. Fruit persistence times after ripening varied both among and within species, at least partly because of varying removal rates, and fruits persisted on some individuals of $I$ rotunda and $I$. viridis until the start of the next flowering season.

\section{Sex ratios}

Sex ratios of flowering plants were male-biased in all large populations ( $>20$ flowering individuals), except for one of 1 . cinerea ( $G$ test; Table 2). In most cases, this male bias was retained even if all nonflowering individuals were assumed to be female. The sex ratios in five large populations of 1 . asprella ranged from $1.12: 1$ to $2.68: 1$ and were significantly heterogeneous among populations $\left(G_{\mathrm{H}}=12.53\right.$, $p=0.014)$. In general, the male bias was present in all size classes, but the smallest size classes had more nonflowering individuals, so it was not possible to distinguish between a male-biased sex ratio and a male bias in flowering among small plants. The mean heights of male and female plants differed significantly ( $t$ test, $p=0.05$ ) in only 2 out of 21 populations, which is similar to the number expected by chance, so there was no evidence of sex-biased mortality.

\section{Flower biology}

Male flowers lasted $1 \mathrm{~d}$ while female flowers remained open for 3-7 d. Male and female flowers of the same species were generally similar in size and petal color (Table 3), although easily distinguishable to human eyes by the presence or absence of the superior ovary. The mean number of flowers produced on an 8-mm-diameter branch was inversely related to flower size (as dry mass) across species (Pearson product moment correlation, males $r=-0.62, p<$ 0.05 ; females $r=-0.75, p<0.005$ ), but male plants produced 2.4-11.2 times as many flowers as female plants (Table 4). Individual female flowers were heavier than male flowers in most species, so floral investment (number of flowers $x$ dry mass) varied less between the sexes, with male investment 0.93-5.84 times that of the females. Nectar volume, rate of production, sugar concentration, and chemistry varied widely among species (Table 3 ).

Apis cerana was by far the commonest diurnal flower visitor, accounting for $>87 \%$ of all flower visits of both sexes for all species (Table 3). Minor diurnal insect visitors included other bees, wasps, butterflies, ants, and beetles. Male flowers of all species received more $A$. cerana visits and total visits than female flowers, although the difference was small in some species. There was no significant relationship between Apis visitation rates per flower and nectar production (as mg nectar sugar-flower-1. $\mathrm{h}^{-1}$ ) or flower size in either sex (simple linear regression, $R^{2}<0.2, p>0.1$ ), but there was a marginally significant relationship between Apis visits per male flower and the mean number of flowers on an 8mm-diameter branch $\left(R^{2}=0.25, p=0.06\right)$ and a very strong relationship between Apis visits per flower and the estimated total number of flowers on the plant in both male (Spearman rank order correlation; $\left.r_{s}=0.75, p=0.006\right)$ and female $\left(r_{s}=\right.$ $0.75, p=0.007$ ) plants. Moths and beetles were the major nocturnal flower visitors, but nocturnal visitation rates were at least two orders of magnitude lower than diurnal rates, so these insects are unlikely to contribute significantly to pollination.

The percent fruit set varied widely among species $(8 \%-$ $72 \%$ ) (Table 3) and was not significantly related to the Apis or total visitation rates to female flowers $\left(R^{2}<0.2, p>0.1\right)$. Total reproductive investment (total flower dry mass plus total fruit dry mass on an 8-mm-diameter branch) was 2.2-8.3 
Table 5. Fruit characters of Ilex species in Hong Kong.

\begin{tabular}{|c|c|c|c|c|c|c|c|c|}
\hline Species & Color & $\begin{array}{l}\text { Diameter } \\
(\mathrm{mm})\end{array}$ & Pulp $^{a}$ & Water $^{b}$ & Total sugars $^{c}$ & Saponins $^{c}$ & $\begin{array}{l}\text { Total phe- } \\
\text { nolics }^{c}\end{array}$ & $\begin{array}{l}\text { Fruit removal } \\
\text { rate }^{d}\end{array}$ \\
\hline I. asprella & Black & 5.90 & 81.9 & 76.9 & 23.8 & 1.9 & 2.4 & 6.8 \\
\hline I. chapaensis & Green & 19.95 & 76.2 & 66.7 & 18.2 & 0.5 & 0.6 & \\
\hline I. cinerea & Red & 6.66 & 66.9 & 65.8 & 50.3 & 0.7 & 1.1 & 20.0 \\
\hline I. ficoidea & Red & 6.05 & 75.8 & 58.9 & 29.5 & 1.2 & 2.0 & 6.0 \\
\hline I. graciliflora & Red & 5.55 & 75.0 & 58.7 & 25.4 & 0.5 & 2.0 & 14.2 \\
\hline I. hanceana & Red & 5.42 & 70.1 & 64.9 & 37.0 & 0.9 & 4.4 & 8.6 \\
\hline I. kwangtungensis & Red & 8.90 & 89.0 & 60.8 & 32.3 & 0.6 & 6.3 & \\
\hline I. limii & Red & 10.21 & 82.9 & 59.7 & & & & \\
\hline I. lohfauensis & Red & 3.92 & 75.5 & 74.0 & 32.8 & 1.2 & 0.3 & 10.1 \\
\hline I. memecylifolia & Red & 5.44 & 86.1 & 72.1 & & & & \\
\hline I. pubescens & Red & 4.59 & 78.5 & 68.7 & 27.1 & 1.0 & 3.2 & 10.3 \\
\hline I. rotunda & Red & 4.54 & 81.7 & 71.8 & 24.3 & 1.5 & 5.0 & 1.5 \\
\hline I. viridis & Black & 6.73 & 53.0 & 56.5 & 28.2 & 1.0 & 3.3 & 3.5 \\
\hline
\end{tabular}

${ }^{a}$ As a percentage of fruit fresh mass.

${ }^{b}$ As a percentage of pulp fresh mass.

'As a percentage of pulp dry mass.

${ }^{d}$ Per 1000 fruits $\cdot \mathrm{h}^{-1}$.

times higher in females than males. except in 1 . lohfuensis. which had the highest number of male flowers and the lowest fruit set (Table 4).

\section{Fruit biology}

Fruit characters varied widely among species (Table 5). llex chapaensis has the most distinctive fruits. They are too large (20 $\mathrm{mm}$ diameter) for any widespread bird species in Hong Kong to swallow whole (Corlett 2002) and their green color, even when fully ripe, makes them inconspicuous in the evergreen forest canopy. They also had the lowest total sugar content, although the other fruit characters were not extreme. No diurnal frugivores were seen visiting this species, but nocturnal observations discovered a masked palm civet (Paguma larvata) in the same individual tree in two consecutive years. Atypically for civets. which usually swallow fruits whole (Dudgeon and Corlett 2004), the animals dropped the fruit skins and some of the pyrenes. Similar remains were found under all fruiting trees of $I$. chapaensis examined. suggesting that masked palm civets are the major consumers of this fruit species in Hong Kong.

The fruits of the other species were black ( $I$. asprella. I. viridis) or red (the others) and consumed by birds. The two most common avian frugivores in Hong Kong, the light-vented bulbul (Pycnonotus sinensis) and the Japanese white-eye (Zosterops japonica), removed most of the fruits of all species. The rates at which fruits were removed by birds (per 1000 fruits per hour) were related to pulp chemistry (all as percentage of wet pulp mass) but not to the percentage of the fruit mass consisting of pyrenes (Table 5). In an all-subsets regression (a procedure that considers all possible regression models). the "best" model for removal rate (minimum Mallow's $C p$ and near maximum adjusted $R^{2}$ ) included sugar, phenolic, and saponin contents $\left(C p=3.04 . R^{2}=0.84\right.$. adj $\left.R^{2}=0.74\right)$. Simple linear regressions showed that fruit removal rates were related positively to sugar content $\left(R^{2}=\right.$ 0.34. $p=0.1)$ and negatively to phenolic $\left(R^{2}=0.58, p=\right.$ $0.016)$ and saponin $\left(R^{2}=0.21, p=0.21\right)$ contents, with only the relationship with phenolics being statistically significant.
It should be noted that sugar contents increased and saponin and phenolic contents decreased over 4 weeks in $I$. asprella and $I$. pubescens, so the chemical analyses for a single collecting date in the other species may not adequately reflect the variation in pulp chemistry to which frugivores are exposed. No tannins were detected in the flesh of any species (in agreement with the results of Gargiullo and Stiles (1991) for two North American species).

\section{Seed biology}

The mean number of pyrenes per fruit ranged from 4.0 ( 7 species) to 6.21 ( $I$. chapaensis), while the percentage of pyrenes containing seeds ranged from $49 \%$ (l. ficoidea) to $90 \%$ (I. pubescens) (Table 6). Most embryos were at the immature. heart-shaped stage when the fruits were mature, but $<40 \%$ of embryos were at the torpedo stage and $<10 \%$ were mature in some species. Germination trials are on-going, but the time to first germination ranged from 2 (I. lohfauensis) to 67 (I. chapaensis) weeks and the percentage that had germinated after 1 year ranged from zero (I. chapaensis) to $62 \%$ (I. memecrlifolia). The relatively rapid germination of I. Lohfalensis is consistent with its relatively mature embryos, but the pattern for other species is less clear.

\section{Discussion}

\section{Ilex in the tropics}

The reproductive biology of most of Hong Kong's Ilex species is similar to that of the well-studied temperate-zone species. As in the temperate zone, the Hong Kong hollies are evergreen or deciduous dioecious trees or shrubs with small Apis-pollinated flowers, most of which produce large, synchronous crops of small. low quality, chemically defended fruits that are eaten by birds and, in some species, can persist for several months after ripening. The large, green. mammal-dispersed fruits of $I$. chapaensis, the shortpersistent summer fruits of 1 . asprella, and the asynchronous fruiting of $I$. memecylifolia do not fit the temperate model. however. All three could be considered adaptations to Hong 
Table 6. Seed characters of Ilex species in Hong Kong.

\begin{tabular}{|c|c|c|c|c|c|c|c|}
\hline \multirow[b]{2}{*}{ Species } & \multirow[b]{2}{*}{$\begin{array}{l}\text { Mean no. of pyr- } \\
\text { enes per fruit }\end{array}$} & \multirow[b]{2}{*}{$\begin{array}{l}\% \text { pyrenes } \\
\text { with seeds }\end{array}$} & \multicolumn{3}{|c|}{ Embryo shape } & \multirow[b]{2}{*}{$\begin{array}{l}\text { Weeks to first } \\
\text { germination }\end{array}$} & \multirow[b]{2}{*}{$\begin{array}{l}\% \text { germination } \\
\text { within } 1 \text { year }\end{array}$} \\
\hline & & & Heart $(\%)$ & $\begin{array}{l}\text { Torpedo } \\
(\%)\end{array}$ & $\begin{array}{l}\text { Mature } \\
(\%)\end{array}$ & & \\
\hline I. asprella & 4.92 & 77.7 & 97.5 & 2.5 & 0.0 & 9 & 32 \\
\hline I. chapaensis & 6.21 & 60.5 & 100.0 & 0.0 & 0.0 & 67 & 0 \\
\hline I. cinerea & 3.99 & 81.7 & 100.0 & 0.0 & 0.0 & 19 & 7 \\
\hline I. ficoidea & 4.00 & 49.3 & 100.0 & 0.0 & 0.0 & 46 & 28 \\
\hline I. graciliflora & 4.00 & 56.6 & 80.0 & 20.0 & 0.0 & 9 & 21 \\
\hline I. hanceana & 3.99 & 65.9 & 95.0 & 5.0 & 0.0 & 8 & 31 \\
\hline I. kwangtungensis & 4.15 & 61.7 & 100.0 & 0.0 & 0.0 & 49 & 14 \\
\hline I. limii & 4.89 & 75.5 & 97.5 & 2.5 & 0.0 & - & 0 \\
\hline I. lohfauensis & 4.01 & 51.8 & 50.0 & 40.0 & 10.0 & 2 & 44 \\
\hline I. memecylifolia & 4.00 & 62.3 & 75.0 & 25.0 & 0.0 & 9 & 62 \\
\hline I. pubescens & 5.56 & 90.1 & 55.0 & 40.0 & 5.0 & 8 & 13 \\
\hline I. rotunda & 5.52 & 74.1 & 60.0 & 40.0 & 0.0 & 3 & 17 \\
\hline I. viridis & 4.00 & 77.0 & 100.0 & 0.0 & 0.0 & 8 & 10 \\
\hline
\end{tabular}

Kong's less seasonal climate and the presence of abundant frugivores year-round. The milder climate may also reduce the advantages of prolonged seed dormancy and thus the advantages of immature embryos, although tropical and subtropical American Ilex species apparently resemble the temperate species in having mostly immature embryos at fruit maturity (Sansberro et al. 1998, 2001).

While many features of the genus are unusual in temperate floras, most aspects of the reproductive biology of Hong Kong's Ilex species do not stand out from those of other woody plants in Hong Kong. Other dioecious species, in genera such as Diospyros, Eurya, Ficus, Litsea, and Mallotus, are prominent in the woody flora of shrublands and secondary forest. Most Ilex species flower during or slightly before the peak flowering period for woody flora of AprilJune and fruit during or slightly before the peak fruiting period of November-January (Corlett 1993). The dominant flower visitor, Apis cerana, was also the most common visitor to $46(55 \%)$ of 83 common woody species investigated by Corlett (2001) and the major frugivores for all Ilex species except I. chapaensis were Pycnonotus sinensis, and Zosterops japonica, which are the two most important seed dispersal agents in Hong Kong (Corlett 1996; Dudgeon and Corlett 2004). With the exception of I. chapaensis, the Ilex species have smaller fruits than most other fleshy-fruited species in Hong Kong (median fruit diameter of 255 species was $8 \mathrm{~mm}$ ), but the fruits of most llex species have a higher percentage of pulp (median 69\% pulp for 255 species) and a lower water content (median $78 \%$ water for 153 species) (Corlett 1996). Sugar content as a percentage of dry mass is apparently lower than that of non-Ilex species (median 53\% sugar for 153 species), but the higher values come from the anthrone method, which is less specific to sugars than the HPLC method used here. Glucose and fructose were the only fruit sugars detected in the Ilex species studied here and in 45 of 56 non-Ilex species included in an earlier study (Ko et al. 1998). Sucrose has been found only in fruits eaten by mammals in Hong Kong, but some fruits eaten by mammals, including several fruits preferred by civets, have only hexose sugars, so the absence of sucrose in I. chapaensis fruits is not unusual.

There are no data on the defensive chemistry of other
Hong Kong fruits, but Tang et al. (2005) measured the persistence times of ripe fleshy fruits of 34 species under natural conditions and with frugivores excluded by nylon mesh bags. Four Ilex species, I. asprella, I. cinerea, I. pubescens, and $I$. viridis, were included in this study. Unbagged persistence, which is a measure of unattractiveness to frugivores, was longer than the non-Ilex median ( $25 \mathrm{~d})$ in all species except $I$. asprella $(14 \mathrm{~d})$, which fruits at a time when little other fruit is available. Bagged persistence, which is a measure of fruit defense against microbes, was shorter than the non-Ilex median $(66 \mathrm{~d})$ in I. asprella $(24 \mathrm{~d})$, similar in I. cinerea $(67 \mathrm{~d})$, and considerably longer in I. viridis ( $85 \mathrm{~d}$ ) and $I$. pubescens $(137 \mathrm{~d})$. This agrees with our subjective impression that the fruits of some Ilex species, particularly I. pubescens, I. rotunda, and I. viridis, are eaten by frugivorous birds only after alternatives have been exhausted. There have been no other local reports of seeds with undeveloped embryos in mature fruits, but I. hanceana, the only Ilex tested, was one of only eight tree species (of 40 tested) to retain viable seeds after being buried for 2 years in the forest (Zhuang and Corlett 1999).

\section{Sex ratios}

Although male-biased sex ratios are widespread in dioecious plants and have been reported for other Ilex species (e.g., Ferreira et al. 1983; Cavigelli et al. 1986; Kay and Stevens 1986; Obeso et al. 1998), the consistency across most species in this study is striking. Male-biased sex ratios among flowering individuals are often assumed to result from gender differences in survival and age at first reproduction, as a result of the differential costs of reproduction in male and female plants, but biased sex ratios may also occur at the seed stage (de Jong and van der Meijden 2004) or result from differential mortality before reproduction (e.g., Decker and Pilson 2000). The only study of an Ilex species that looked at the seedling sex ratio found equal numbers of males and females (Clark and Orton 1967), suggesting a primary (genetic) sex ratio of $1: 1$. In most populations in this study, the male bias is retained even if all nonflowering individuals are assumed to be female, showing that earlier or more frequent flowering in males does not explain the observed sex ratios. Reproductive investment is 
generally much higher in females than males. which might be expected to result in higher female mortality, but the size structures of male and female subpopulations do not provide any support for this. This suggests that there is already a male-biased genet ratio by the time the plants reach reproductive size, although it was not possible to test this with the data available. The significant heterogeneity in sex ratio among populations of $I$. asprella could then be explained by environmental influences on sex differences in pre-reproductive mortality. The five populations differed considerably in environment and population density, but there were too many potential variables and too few replicates for post-priori tests. Further work is clearly needed on the dynamics of sex ratios in Ilex. ideally using molecular markers for gender.

\section{Comparisons among species}

The results of the regressions relating bee and bird visits to flower and fruit characteristics must be viewed with caution, since our inability to correct for possible phylogenetic effects may have resulted in inflation of the degrees of freedom. The positive relationship between Apis visitation rates and the number of flowers per plant, but not the characteristics of individual flowers. requires further investigation. Many previous studies have shown that bees spend longer times in larger flower patches, but in the majority of these studies they visited a smaller proportion of the available flowers as patch size increased (Goulson 2000), the opposite of the pattern observed here. However, these studies have mostly used a single plant species with hermaphrodite flowers, and it is not obvious that the same considerations would apply in comparisons among dioecious species. Geitonogamy, which has been considered the major cost of large floral displays (Barrett 2003), is avoided in dioecious plants. but large displays are still likely to reduce the frequency of interplant movements, and thus pollination. The number of flowers per plant also varies greatly within species, so future studies could compare the effects of within and between species variation in flower numbers on both visitation rates and the movements of individual bees.

The observed relationship between fruit removal rate and fruit chemistry was in the expected direction (positive for nutrition. negative for defense), although the strength of the relationship is surprising given the uncontrolled differences in frugivorous bird density among sites and the changes in chemistry as fruits ripen. A variety of evidence suggests that fruit chemistry reflects an adaptive balance between attracting dispersers and deterring pests and pathogens (Cipollini et al. 2004; Tang et al. 2005). There is also evidence that frugivores can detect small differences in fruit quality (e.g.. Schaefer et al. 2003a) and that ranking of fruit preferences is fairly consistent across sites and time (Herrera 1998; Carlo et al. 2003). In one of the few studies that studied fruit removal by an entire frugivore community under natural conditions, rapidly removed fruits had higher nutrient levels (carbohydrate, lipid. and nitrogen) and lower defenses (phenolics) than more persistent fruits, in agreement with our results (Schaefer et al. 2003b). However, higher removal rates do not necessarily benefit the plant. if most fruits are eventually removed by frugivores, as is the case with Ilex species in Hong Kong (A.C.W. Tsang, personal observation).

\section{Conclusions}

The results of this study considerably extend our knowledge of the largest genus of woody dioecious plants. Unsurprisingly, the $14 / / \mathrm{e} x$ species covered here add to the known range of variation in the reproductive biology of the genus. but the overall picture is still one of considerable uniformity. which makes the genus instantly recognizable by the flowers or fruits. No single trait stands out as a possible reason for the extraordinary global success of this genus. which forms a major component of plant communities in a wide range of environments and in competition with very different local floras. Like other widespread and successful clades, the genus /lex appears to occupy a distinct volume of niche space that allows it to coexist in a variety of different species assemblages (Vitt and Pianka 2005). However, any conclusions on the genus as a whole are premature when the majority of the species and the majority of the environmental and geographical range of the genus remain unstudied.

\section{Acknowledgements}

We thank $\mathrm{Ng}$ Sai-chit for help in the field and Laura Wong for help in the field and laboratory. Lawrence Ramsden provided HPLC equipment for analyzing the nectar and J.D. Gu provided equipment for analyzing the saponins and phenolics. A.C.W.T. was supported by a Postgraduate Studentship from the University of Hong Kong.

\section{References}

Andrews. S. 1998. Book reviews. Hollies: the genus /lex by Fred C Galle. Horticulturalist, 7: 36.

Arrieta. S.. and Suárez. F. 2005. Spatial dynamics of Ilex aquifolitm populations seed dispersal and seed bank: understanding the first steps of regeneration. Plant Ecol. 177: 237-24l.

Barrett. S.C.H. 2003. Mating strategies of flowering plants: the outcrossing-selfing paradigm and beyond. Philos. Trans. R. Soc. Lond. B Biol. Sci. 358: 991-1004. PMID: 12831464.

Baskin. C.C., and Baskin. J.M. 2001. Seeds: ecology, biogeography, and evolution of dormancy and germination. Academic Press. San Diego.

Carlo, T.A., Collazo, J.A., and Groom, M.J. 2003. Avian fruit preferences across a Puerto Rican forested landscape: pattern consistency and implications for seed removal. Oecologia. 134: 119-131. doi: 10.1007/s00442-002-1087-1. PMID: 12647189.

Carr. D.E. 1992. The relationship between crop size and fruit removal and its implication for the evolution of dioecy. Can. J. Bot. 70: 1784-1789.

Cavigelli. M.. Poulos. M.. Lacey. E.P.. and Mellon. G. 1986. Sexual dimorphism in a temperate dioecious tree, llex montana (Aquifoliaceae). Am. Midl. Nat. 115: 397-406.

Cipollini, M.L., Paulk. E.. Mink. K., Vaughn. K.. and Fischer. T. 2004. Defense tradeoffs in fleshy fruits: effects of resource variation on growth. reproduction. and fruit secondary chemistry in Solanum carolinense. J. Chem. Ecol. 30: 1-17. doi: 10.1023/ B:JOEC.0000013179.45661.68. PMID: 15074654.

Clark. R.B.. and Orton. E.R. 1967. Sex ratio in Ilex opaca Ait. HortScience. 2: 115.

Corlett, R.T. 1993. Reproductive phenology of Hong Kong shrubland. J. Trop. Ecol. 9: 501-510.

Corlett, R.T. 1996. Characteristics of vertebrate-dispersed fruits in Hong Kong. J. Trop. Ecol. 12: 819-833.

Corlett. R.T. 2001. Pollination in a degraded tropical landscape: a 
Hong Kong case study. J. Trop. Ecol. 17: 155-161. doi: 10. 1017/S0266467401001109.

Corlett, R.T. 2002. Frugivory and seed dispersal in degraded tropical East Asian landscapes. In Seed dispersal and frugivory: ecology, evolution and conservation. Edited by D.J. Levey, W.R. Silva, and M. Galetti. CAB International, Wallingford, UK. pp. $451-465$.

Cuénoud, P., Martinez, M.D.P., Loizeau, P.A., Spichiger, R., Andrews, S., and Manen, J.F. 2000. Molecular phylogeny and biogeography of the genus Ilex L. (Aquifoliaceae). Ann. Bot. (Lond.), 85: 111-122.

Decker, K.L., and Pilson, D. 2000. Biased sex ratios in the dioecious annual Croton texensis (Euphorbiaceae) are not due to environmental sex determination. Am. J. Bot. 87: 221-229. PMID: 10675309.

de Jong, T.J., and van der Meijden, E. 2004. Sex ratio of some long-lived dioecious plants in a sand dune area. Plant Biol. 6 : 616-620. doi: 10.1055/s-2004-821177. PMID: 15375733.

Dudgeon, D., and Corlett, R.T. 2004. The ecology and biodiversity of Hong Kong. Joint Publishing, Hong Kong.

Ferreira, A.G., Kaspary, R., Ferreira, H.B., and Rosa, L.M. 1983. Proporção de sexo e polinização em llex paraguariensis St. Hill. Brasil Florestal, 53: 29-33.

Galle, F.C. 1997. Hollies: the genus llex. Timber Press, Portland, Oregon.

Gargiullo, M.B., and Stiles, E.W. 1991. Chemical and nutritional differences between two bird-dispersed fruits: llex opaca and Ilex verticillata. J. Chem. Ecol. 17: 1091-1106. doi: 10.1007/ BF01402936.

Gorchov, D.L. 1990. Pattern, adaptation, and constraint in fruiting synchrony within vertebrate-dispersed woody plants. Oikos, 58: 169-180.

Goulson, D. 2000. Why do pollinators visit proportionally fewer flowers in large patches? Oikos, 91: 485-492. doi: 10.1034/j. 1600-0706.2000.910309.x.

Hagerman, A.E. 1987. Radial diffusion method for determining tannin in plant extracts. J. Chem. Ecol. 13: 437-449. doi: 10 . 1007/BF01880091.

Herrera, C.M. 1998. Long-term dynamics of Mediterranean frugivorous birds and fleshy fruits: a 12-year study. Ecol. Monogr. 68: $511-538$.

Hiai, S., Orua, H., and Nakajima, T. 1976. Color reaction of some sapogenins and saponins with vanillin and sulfuric acid. Planta Med. 29: 116-122. PMID: 948509.

Hu, C.Y. 1975. In vitro culture of rudimentary embryos of eleven Ilex species. J. Am. Soc. Hortic. Sci. 100: 221-225.

Kay, Q.O.N., and Stevens, D.P. 1986. The frequency, distribution and reproductive biology of dioecious species in the native flora of Britain and Ireland. Bot. J. Linn. Soc. 92: 39-64.

Ko, I.W.P., Corlett, R.T., and Xu, R.J. 1998. Sugar composition of wild fruits in Hong Kong, China. J. Trop. Ecol. 14: 381-387. doi: $10.1017 / \mathrm{S} 0266467498000297$

Krell, R. 1988. Honey bee foraging activities and nectar secretion of gallberry ( $I$. glabra L.) in the coastal plain of Georgia. Ph.D. thesis, Department of Entomology, University of Georgia, Athens, Ga.

Loizeau, P.A., and Spichiger, R. 2004. Aquifoliaceac. In Flowering plants of the Neotropics. Edited by N. Smith, S.A. Mori,
A. Henderson, D.W. Stevenson, and S.V. Heald. Princeton University Press, Princeton, N.J. pp. 26-28.

Manen, J.F., Boulter, M.C., and Naciri-Graven, Y. 2002. The complex history of the genus Ilex L. (Aquifoliaceae): evidence from the comparison of plastid and nuclear DNA sequences and from fossil data. Plant Syst. Evol. 235: 79-98. doi: 10.1007/ s00606-002-0225-x.

Naka, K., and Yoda, K. 1984. Community dynamics of evergreen broadleaf forests in southwestern Japan. II. Species composition and density of seeds buried in the soil of a climax evergreen oak forest. Bot. Mag. Tokyo, 97: 61-79.

Obeso, J.R., and Fernandez-Calvo, I.C. 2003. Fruit removal, pyrene dispersal, post-dispersal predation and seedling establishment of a bird-dispersed tree. Plant Ecol. 165: 223-233. doi: 10.1023/ A: 1022241207296 .

Obeso, J.R., Santullano, M.A., and Retueroto, R. 1998. Sex ratios, size distributions, and sexual dimorphism in the dioecious tree Ilex aquifolium (Aquifoliaceae). Am. J. Bot. 85: 1602-1608.

Price, M.L., and Butler, L.G. 1977. Rapid visual estimation and spectrophotometric determination of tannin content of sorghum grain. J. Agric. Food Chem. 25: 1268-1273. doi: 10.1021/ jf60214a034.

Rathcke, B. 1988. Flowering phenologies in a shrub community: competition and constraints. J. Ecol. 76: 975-994.

Sansberro, P.A., Rey, H.Y., Mroginski, L.A., and Collavino, M.M. 1998. In vitro culture of rudimentary embryos of Ilex paraguariensis: responses to exogenous cytokinins. Plant Growth Regul. 17: $101-105$

Sansberro, P.A., Rey, H.Y., and Mroginski, L.A. 2001. In vitro culture of zygotic embryos of llex species. HortScience, 36: 351352.

Schaefer, H.M., Schmidt, V., and Bairlein, F. 2003a. Discrimination abilities for nutrients: which difference matters for choosy birds and why? Anim. Behav. 65: 531-541. doi: 10.1006/anbe. 2003.2089.

Schaefer, H.M., Schmidt, V., and Winkler, H. 2003b. Testing the defence trade-off hypothesis: how contents of nutrients and secondary compounds affect fruit removal. Oikos, 102: 318-328. doi: 10.1034/j.1600-0706.2003.I1796.x.

Shelton, M.G., and Cain, M.D. 2002. Potential carry-over of seeds from 11 common shrub and vine competitors of loblolly and shortleaf pines. Can. J. For. Res. 32: 412-419. doi: 10.1139/ x01-207.

Snow, B.K., and Snow, D.W. 1988. Birds and berries. A study of an ecological interaction. T \& A D Poyser Ltd., Calton, UK.

Tang, A.M.C., Corlett, R.T., and Hyde, K.D. 2005. The persistence of ripe fleshy fruits in the presence and absence of frugivores. Oecologia, 142: 232-237. doi: 10.1007/s00442-004-1730-0. PMID: 15517410.

Vitt, L.J., and Pianka, E.R. 2005. Deep history impacts present-day ecology and biodiversity. Proc. Natl. Acad. Sci. USA, 102: 7877-7881. doi: 10.1073/pnas.0501104102. PMID: 15867150.

Zhuang, X.Y., and Corlett, R.T. 1997. Forest and forest succession in Hong Kong, China. J. Trop. Ecol. 14: 857-866.

Zhuang, X.Y., and Corlett, R.T. 1999. Study on seed ecophysiological characteristics of tree species in secondary forest of Hong Kong. Ecol. Sci. 18: 1-6. [In Chinese.] 